\title{
POND, STREAM OR LAKE, $\Lambda$ S A STIMULUS TO MORE PRACTICAL WORK IN BIOLOGY AND PHYSIOGRAPHY.
}

\author{
By R. W. Sharpe. \\ Instructor in Science, New Trier Tozenship High School, Cook \\ County, Illinois.
}

The characteristic tendency of secondary school science of to-day is to lay greater stress on obtaining knowledge at first hand. In fact; though on a smaller scale and in a way fitted to the comprehension of younger students, we are attempting to do what the colleges will ask of the same students at a later day.

That this is a sane method of obtaining information seems beyond cavil. The person who must gather all his information at second hand from some other source or authority, is likely to be badly misled at some time or other, not to speak of the lack of independence which he must experience all through life. While a great amount of our information may-probably must--be derived from books, yet there must be a background of personal experience to make the information gained of real worth. All teachers experience great difficulty with younger pupils, with their almost exclusively bookish education, in getting them to realize what the study of the thing itself is, or means. They are quite ready, in a parrot-like fashion, to repeat whatever may be given in text-books, or what has been told them, yet to form their own ideas from the real thing is a bug-a-boo indeed.

Educational authorities have of late years begun to realize all this, and the laboratory idea is just now being entertained with unusual seriousness by school boards of this and other states. Where formerly classes in physics, chemistry and biology did little more than memoriter recitation work from text-books, we now find some sort of provision made for genuine contact with nature, if little more than an improvised shed where the pupils gather together to study the results of a foraging expedition.

Amusing, yet how instructive, the early struggles of scientists in developing the laboratory idea! Up to the middle of the 17 th century little real progress had been made, principally because of the lack of an organized body of scientists, where the aftrition of like minds, making suggestions to each other, criticising, comparing and reasoning, might act as a stimulus to a productive 
intellectual activity. This element was introduced by the organization of the Royal Society of London and the Academy of Sciences of Paris.

That the embryonic investigators of these socicties had troubles of their own is amusingly illustrated by the following instances: One inquiry was sent all the way to Batavia, to know "whether there be a hill in Sumatra which burneth continually, and a fountain which runneth pure balsam." Another, to this country, was concerning the stupefying herb Datura, "whether the Indians make it lie several days, months or years, according as they will, in a man's body, without doing him any harm, and at the end kill him without missing an hour's time." Another was "whether there be a tree in Mexico that yields water, wine, vinegar, milk, honey, wax, thread and needles."

Of historical interest is the work of Robert Hooke, about the middle of the 17th century, where he appeared before the Royal Society of London and obtained the affidavits of its members to the effect that they had really seen certain small animals in a drop of water-animals that we now call protozoans.

But enough of this. The spectacle of Agassiz at Penikese is still before us, and all that remains is to provide the time in our school programs and furnish proper leaders and we will have pupils genuinely enthusiastic over the study of their surroundings. At the same time just enough of the commercial spirit of the age should be injected into their work as may lead them, as well as their parents, to feel that they are really accomplishing something of far reaching value, other than learning the scientific names of some insects, trees or flowers, or perchance becoming familiar with methods of dissection and the technology of the microscope.

Permit me to say, in this connection, that I know of no more active and enthusiastic workers along this line than Doctors Forbes, Burrill and Davenport, of our own State University. Their publications regarding the fauna and flora of the state are exceedingly helpful and suggestive, and just now the Illinois State Laboratory of Natural History is sending out to the high schools of the state named collections of Illinois insects of economic importance, accompanicd by a brief mantal of the more interesting facts concerning them. A genuine interest is being awakened, and even the rural schools are being reached with a 


\section{Thork in Jbiology and pbystograpby}

reviving spirit which is truly remarkable. Agricultural clubs are being formed and farm brceding contests are being entered into with enthusiasm and profit. In fact, it seems to me that we of the high schools may well profit by a study and imitation of the methods used in some of our rural schools along these lines. Personally, I believe the time has come when all, even the smaller of our high schools, should offer a year's course in scientific agriculture, closely correlated with physiography and biology-the inmediate surroundings being the subject matter of study.

To quote Thomson in his "Study of Animal Life," "We do not want to know all that is contained, even in Chambers' Encyclopedia, though we wish to gain the power of understanding, realizing and enjoying the various aspects of the world around us. We do not wish brains laden with chemistry and physics, astronomy and geology, botany and zoölogy and other sciences, though we would have our eyes lightened so that we may see into the heart of things, our brains cleared so that we may understand what is known and unknown when we are brought naturally in the face of problems, and our emotions purified so that we may feel more and more fully the joy of life." Perhaps another familiar quotation may be permitted here: "A circuitous course of study followed with natural eagerness, will lead to better results than the most logical of programs if that take no root in the life of the student." Indeed, in the latter part of this statement lies my excuse for the quotation. Encourage and broaden the practical interest, and it naturally becomes geographical and physiographical, leading up to the natural history of the region being surveyed. This seems little but common sense, yet we seem to realize but little how important this may be to the boy or girl, who has most likely never been able to conccive of a really intelligent interest of any certain subject under discussion, but is familiar with it only "a memoriter."

In endeavoring to carry out these ideas, no better subject for teacher and students can be found than the immediate neighborhood of the school itself, especially as there are but few such neighborhoods that do not afford a pond, garden, small lake or stream for special study. Here is a source of work for all the different departments of the school--its study will afford opportunity for the English department, the mathematics department and even the history department. Ourpondorstream must be measured, 
its shape determined and mapped, its position, depth, and other peculiarities made out; this, of course, implies noting the facts, writing them down, thinking about them, and finally writing ont the full account. The class in physiography may well take care of the temperature observations, noting the rainfall, snow, frost, clouds, winds and storms. The classes in biology will be interested in finding out the kinds of animals and plants inhabiting the region or growing on its banks, noting their habits, numbers, distribution and feeding habits. It is becoming more and more of a truism that what the students in our schools need more than anything cise is experience and practice in secing things as they really are. It is difficult to conceive how any school could possibly offer training of any more value than that to be obtained by patiently observing the phenomena of its own surroundings.

To quote an eminent authority, Dr. B. W. Evermann, now with the United States Fish Commission, "A child taught to study his surroundings will be really edtcated; he will have had eight to twelve years of actual doing, instead of that number of years of parrot work and lifeless memorizing that the schools are now giving. He will be self-reliant; will know the value of evidence and the little value of authority; will possess real knowledge instead of book misinformation; moreover, he has learned to do by doing and knows how to do things. There is little danger of a child so educated ever falling a prey to any of the frauds or fallacies at the present time so prevalent in this country."

An outline somewhat similar to the following, which has been adopted from one used by the United States Fish Commission, might very readily be made to do service, and if carried throughout a period of time, say not less than a year, the results would be a real contribution to knowledge, well worth publishing in the local papers, and even in popular and scientific periodicals.

The outline here given is very briefly suggested, and for convenience is subdivided into the physical features and the biological features of any small local area, such as a pond, stream or lakethe one being the special work of the classes in physiography, the other of the classes in zoology and botany.

PHYSICAI, FEATURLS.

a. Geographic position.

1. Size, form, length and width, length of shore line. 
2. Hydrography: average depth, topography of bottom, stages of water.

3. Character of shores: low or high, sandy, gravelly, rocky or marshy.

4. Catchment basin: extent, general character, wooded or other vegetation.

5. Inlets: character and extent, as to direction, volume, etc., outlet.

6. Botton: whether of mud, sand, gravel, rock, muck, marl, etc.

7. Meteorology: amount of precipitation and evaporation, time and character of rains, winds, sky, air, temperature, etc.

8. Character of water, chemical and physical, including purity, hardness, character and source of impurities, clearness, etc.

9. Observations daily of temperature of water at surface, bottom, etc.

10. Phenomena connected with the formation of ice, when it forms, maximum thickness, air holes and their relation to life in the pond, ctc.

\section{b. BIOLOGICAL FEATUEHS. \\ I. Zoological.}

1. Plankton.-Species of protozoa or other small forms of animal life entering into the plankton of the pond, showing vertical and horizontal distribution, abundance at different seasons, effect of rains, winds, temperature, etc.; relation to other animal life of the pond.

2. Crustaceans.-Species, abundance, distribution, value, etc

3. Mollusks.- Same as with crustaceans.

4. Similar obscrvations and information concerning the species of the various other groups of aquatic animals occurring in the pond, including the turtles, batrachians, worms, insects, etc.

5. Fishes.-Abundance, distribution, fecding habits, ctc.

6. Mammals.-List of those found about the pond, paying special attention to those living in or about the water; their habits, whether they feed upon fishes, mollusks or othicr aquatic animals.

7. Birds.-The species found about the pond, including the permanent residents, summer residents, spring and fall migrants and winter visitants, paying special attention to the water birds; time of arrival of each species in the spring, how long they remain, when they return in the fall and how long they stay; feeding 
habits, especially of the ducks, grebes, herons, kingfishers, and the like; influence of water birds in keeping open places in the ice during winter.

8. Odonata, lepidoptera, and other insects about the pond whose larvae may appear in the water; mosquito larvae, etc.

\section{Botanical.}

1. Aquatic vegetation. a. Fixed species-List of species growing in fixed position in the water, abundance, distribution and life history of each; time of their first appearance in the spring, flowering, fruiting, and disappearance in the fall; shade and other prolective values; relation of aquatic vegetation $t$ ) absorbed gases in the water.

2. Plankton.-Algae and other plants, both vertical and horizontal distribution, abundance at different seasons, etc., as with the animals.

3. Marsh species.

4. Shore vegetation.

\section{A SIMPLE METHOD OF DETERMINING THE INDEX OF REFRACTION OF LIGHT FROM WATER INTO AIR. \\ By George B. Masseick. John Marshall High School, Chicago.}

Place a measuring stick in a battery jar, or other glass vessel with perpendicular sides, upright against one side. Note the interior height and with another stick determine the distance from the face of the first stick to the opposite side of the jar, the diameter of the available jar, both of these measurements to be within $1 \mathrm{~mm}$. Set the jar on the floor or in a low sink in such a position that another pupil seated or standing can see over one edge of the jar to the stick upright against the farther side of the jar. (The pupil's eye must be somewhat higher than the top of the jar to avoid total reflection.) Note the reading of the line on the stick just visible over the top of the jar. Carefully fill the jar full of water and record the lowest reading now visible from the same position. A pen or pencil moved along the stick down into the water will make this reading easicr. 'It should be made with great 